\title{
Correction to: Functional Polymorphism Located in the microRNA Binding Site of the Insulin Receptor (INSR) Gene Confers Risk for Type 2 Diabetes Mellitus in the Bangladeshi Population
}

\section{Mahrima Parvin ${ }^{1}$. Farhana Jahan ${ }^{1}$. Pankaj Kumar Sarkar ${ }^{2}$.}

Zakir Hossain Howlader ${ }^{3}$. A. H. M. Nurun $\mathrm{Nabi}^{1}$. Md. Ismail Hosen ${ }^{1,3}$

Published online: 30 July 2018

(c) Springer Science+Business Media, LLC, part of Springer Nature 2018

\section{Correction to: Biochemical Genetics https://doi.org/10.1007/s10528-018-9872-7}

The original version of this article unfortunately contained a mistake in the co-author name. It should be Farhana Jahan instead of Farhan Jahan.

The original article has been corrected.

The original article can be found online at https://doi.org/10.1007/s10528-018-9872-7.

Md. Ismail Hosen

ismail.hosen@du.ac.bd

1 Laboratory of Population Genetics, Department of Biochemistry and Molecular Biology,

University of Dhaka, Dhaka 1000, Bangladesh

2 Dinajpur Diabetes O Swasthoseba Hospital, Dinajpur, Bangladesh

3 Nutritional Biochemistry Laboratory, Department of Biochemistry and Molecular Biology,

University of Dhaka, Dhaka, Bangladesh 